Scientia Agricola

http://dx.doi.org/10.1590/0103-9016-2015-0005

\title{
Rock biofertilizer and earthworm compost on sugarcane performance and soil attributes in two consecutive years
}

\author{
Newton Pereira Stamford ${ }^{1}$, , Djalma Eusébio Simões Neto ${ }^{1}$, Ana Dolores Santiago de Freitas ${ }^{1}$, Emídio Cantídio Almeida Oliveira ${ }^{1}$, \\ Wagner Silva Oliveira ${ }^{1}$, Leila Cruz $^{2}$
}

'University Federal Rural of Pernambuco - Dept. of
Agronomy, Soil Science - 52071-900 - Recife - Brazil.
University Federal of Alagoas - Center of Agricultural
Science, BR 104 (km 85) - 57100-00 - Rio Largo, Alagoas
- Brazil.
${ }^{*}$ Corresponding author <newtonps@depa.ufrpe.br>

Edited by: Vinicius de Melo Benites

\begin{abstract}
The deployment of soluble fertilizers has been one of the most commonly applied agricultural practices in the bid to increase crop yield. However, the production of soluble fertilizers has a considerable economic cost and consumes a substantial amount of energy. In general, soil organic matter provides the nutrients needed for plant growth in organic agriculture. However, these nutrients are not sufficient if the best yield is to be obtained. The aim of our field experiment was to evaluate the effectiveness of phosphate and potassic sources (rocks, biofertilizers and soluble fertilizers) based on several sugarcane characteristics and soil attributes. Our experiment was conducted over two consecutive years, and we assessed the effect of using sugarcane filter mud cake (SFMC). In addition, we mixed the phosphate and potassic sources with earthworm compost enriched in $\mathrm{N}$ by inoculation with diazotrophic bacteria (OM) and applied at 50, 100 and $150 \%$ of the recommended dosage rate (RDR). The PK biofertilizer with $\mathrm{OM}$ enriched in $\mathrm{N}$ positively affected sugarcane height, yield, and industrial characteristics. The application of SFMC greatly increased available $\mathrm{P}$ and $\mathrm{K}$ in the soil and plant characteristics with residual effect in the two consecutive harvests. We conclude that the biofertilizer has the potential to increase sugarcane characteristics and may represent an alternative to soluble fertilizers. Keywords: Acidithiobacillus, organic fertilization, organic matter, soil nutrients, sulfur oxidation
\end{abstract}

Received January 19, 2015

Accepted June 29, 2015 with organic matter has been reported in experiments using annual plants, such as cowpea (Stamford et al., 2008, 2011) and melon (Oliveira et al., 2014), grown in both acidic and alkaline soils.

The goal of this study was to evaluate the effectiveness of biofertilizer produced from $\mathrm{P}$ and $\mathrm{K}$ rocks with elemental sulfur inoculated with Acidithiobacillus bacteria and with earthworm compost. In addition, we tested the use of sugarcane filter mud cake (SFMC) to provide nutrients for plant growth and to neutralize the acidity of the PK rock biofertilizer. The PK sources (rocks and biofertilizers) applied at different dosage rates were compared with soluble fertilizers, and their effects on the growth and industrial characteristics of sugarcane and several soil attributes were assessed based on two consecutive crop seasons.

\section{Materials and Methods}

A field experiment was conducted on a sugarcane field located in Goiana, Pernambuco, Brazil $107^{\circ} 33^{\prime} \mathrm{S}$ and $35^{\circ} 00^{\prime} \mathrm{W}$; altitude $13 \mathrm{~m}$ ). A sandy loam soil, representative of the Typic Fragiudult from the tableland rainforest region with low available $\mathrm{P}$ and $\mathrm{K}$ levels, was used. Based on Embrapa methodology (2009), a soil analysis from samples collected from the experimental area (0-30 cm layer) produced the following values: $\mathrm{pH}$ $\left(\mathrm{H}_{2} \mathrm{O} 1.0: 2.5\right)$ of 6.0 , total $\mathrm{N}$ of $0.6 \mathrm{~g} \mathrm{~kg}^{-1}$, organic $\mathrm{C}$ of $8.7 \mathrm{~g} \mathrm{~kg}^{-1}$, and available $\mathrm{P}$ of $4.2 \mathrm{mg} \mathrm{kg}^{-1}$. The exchangeable cation concentrations were as follows: $\mathrm{Ca}^{2+}$ of 10.0 $\mathrm{mmol}_{\mathrm{c}} \mathrm{kg}^{-1}, \mathrm{Mg}^{2+}$ of $8.8 \mathrm{mmol}_{\mathrm{c}} \mathrm{kg}^{-1}$, and $\mathrm{K}^{+}$of $1.2 \mathrm{mmol}_{\mathrm{c}}$ $\mathrm{kg}^{-1}$. A physical analysis revealed the following: soil par- 
ticle density of $2.65 \mathrm{~g} \mathrm{~kg}^{-1}$ and bulk density of $1.54 \mathrm{~g}$ $\mathrm{kg}^{-1}$. Finally, a granulometric analysis showed the following characteristics: coarse sand, fine sand, silt, and clay concentrations of $740.0 \mathrm{~g} \mathrm{~kg}^{-1}, 210.0 \mathrm{~g} \mathrm{~kg}^{-1}, 10.0 \mathrm{~g}$ $\mathrm{kg}^{-1}$, and $40.0 \mathrm{~g} \mathrm{~kg}^{-1}$, respectively.

The rock biofertilizers used in this study were produced from $\mathrm{P}$ natural phosphate and $\mathrm{K}$ rock (biotite), using two furrows (each 10.0-m long, 1.0-m wide and $0.5-\mathrm{m}$ deep). For each biofertilizer, $4000 \mathrm{~kg}$ of natural phosphate (total $\mathrm{P}=240.0 \mathrm{~g} \mathrm{~kg}^{-1}$ ) purchased from Irecê (Bahia, Brazil) and $4000 \mathrm{~kg}$ of potash rock (biotite; total $\mathrm{K}=100.0 \mathrm{~g} \mathrm{~kg}^{-1}$ ) from Santa Luzia (Paraiba, Brazil) were mixed with $400 \mathrm{~kg}$ of elemental sulfur inoculated with Acidithiobacillus thiooxidans following the methodology of Stamford et al., (2008).

The sulfur oxidative bacteria grew in $2000 \mathrm{~mL}$ Erlenmeyer flasks containing $1000 \mathrm{~mL}$ of specific culture medium (El Tarabily et al., 2006); the culture was sterilized for $30 \mathrm{~min}$ at $120{ }^{\circ} \mathrm{C}$ and shaken $(150 \mathrm{rpm})$ for 5 days at $30{ }^{\circ} \mathrm{C}$. These materials (phosphate, potash rocks and elemental sulfur inoculated with Acidithiobacillus) were incubated for 60 days, and water content was maintained at a level that was near the field holding capacity. To avoid the effects of excessive moisture due to rain and to increase the efficiency of the oxidative bacteria, the furrows were covered every day using black plastic. An analysis of BP and BK extracted by (A) Mehlich 1 solution and (B) citric acid according to Embrapa (2009) yielded the following results: BP-biofertilizer $\mathrm{pH}=3.8$, available $\mathrm{P}(\mathrm{A})=60 \mathrm{~g} \mathrm{~kg}^{-1}$, available $\mathrm{P}(\mathrm{B})=48 \mathrm{~g} \mathrm{~kg}^{-1}$, BK biofertilizer $\mathrm{pH}=3.3$, available $\mathrm{K}(\mathrm{A})=10 \mathrm{~g} \mathrm{~kg}^{-1}$ and available $\mathrm{K}(\mathrm{B})=0.5 \mathrm{~g} \mathrm{~kg}^{-1}$.

The soil was prepared for sugarcane cultivation, cutting and removal of all vegetation in the experimental area that had not been cultivated for five years following conventional tillage with one plow and two disk operations. Afterwards, rows were simultaneously opened for sugarcane stalk planting and fertilizer application. Each plot had five 10-m-long rows separated by $1 \mathrm{~m}$; data were collected from the two central rows $\left(10 \mathrm{~m}^{2}\right)$ only. Irrigation and other management practices followed the recommendations of the Sugarcane Industry.

The experiment was conducted in an incomplete factorial $(3 \times 3+1)+3$ randomized block design with four replicates. We used 3 sources of PK (rocks, biofertilizers and soluble fertilizers) applied at 50, 100 and $150 \%$ of the recommended dosage rate (RDR). The PK sources were mixed with organic matter (OM) produced from earthworm compost enriched with $\mathrm{N}$ produced by selected free-living diazotrophic bacteria in accordance with Lima et al., (2010). The fertilization treatments were tested in two consecutive crop seasons with and without SFMC. The SFMC was applied at a dosage rate of $40 \mathrm{tha}^{-1}$.

The amount of PK biofertilizer was calculated based on $\mathrm{P}$ and $\mathrm{K}$ soluble mineral fertilizers by using the same amount for each corresponding treatment and following the RDR for sugarcane in Pernambuco (IPA,
2008). Based on experimental results, the fertilizer and biofertilizer application dosage rates were the same: dosage $1=80 \mathrm{~kg} \mathrm{ha}^{-1}$, dosage $2=160 \mathrm{~kg} \mathrm{ha}^{-1}$ and dosage 3 $=240 \mathrm{~kg} \mathrm{ha}^{-1}$. For rocks, the dosage rates were the following: dosage $1=160 \mathrm{~kg} \mathrm{ha}^{-1}$, dosage $2=320 \mathrm{~kg} \mathrm{ha}^{-1}$ and dosage $3=480 \mathrm{~kg} \mathrm{ha}^{-1}$.

The $\mathrm{P}$ and $\mathrm{K}$ soluble fertilizers contained simple superphosphate $\left(20 \% \mathrm{P}_{2} \mathrm{O}_{5}\right)$ and potassium sulfate (50 $\left.\% \mathrm{~K}_{2} \mathrm{O}\right)$, respectively. We determined the plant yields and heights. Moreover, several sugarcane characteristics were assessed, such as the soluble solid concentration (Brix), apparent sucrose (Pol), purity (Pur) and total recoverable sugars (TRS). Technical analyses were conducted following the methodology used in the Sugarcane Industry. Several soil chemical attributes were analyzed (Embrapa, 2009), to test the effects of the different fertilization treatments in two consecutive harvests with and without SFMC.

A statistical analysis was performed utilizing SAS (SAS Institute, 2011) version 11.0 using Tukey's test to compare the means $(p>0.05)$.

\section{Results and Discussion}

The heights of sugarcane plants subjected to the different fertilization treatments are shown in Table 1. Significantly positive effects of sugarcane fertilization were observed, especially in plants that received biofertilizer applications at greater rates. The effects of sugarcane residues were described by Dario et al., (2003), who found an increase in sugarcane yield under field conditions. Kaur et al., (2005) also described significant effects of nutrients in the shoot height of sugarcane. However, our results show that plants that received the biofertilizer treatment were taller and significantly different from plants that received the mineral soluble fertilizer treatment for all application rates. These results demonstrate the potential of biofertilizer application for sugarcane.

The sugarcane yields in the two cropping years are presented in Table 2. The effectiveness of the PK rock biofertilizers mixed with earthworm compost is evident; the best results were obtained when applied at the highest dosage rates. These results are in agreement with Santos et al., (2010), who found a correlation between sugarcane yield and fertilizer application. Moreover, Santos et al., (2010) found that organic matter promoted a higher yield in sugarcane, probably because the organic matter released $\mathrm{P}, \mathrm{Ca}$ and other nutrients that are necessary for plant nutrition. Likewise, these results are in agreement with the greenhouse studies of Stamford et al., (2006, 2008). These authors concluded that a PK rock biofertilizer mixed with earthworm compost may be an alternative to mineral soluble fertilizers. Furthermore, residual fertilizer effects may be observed, especially when applying PK rock biofertilizer mixed with sugarcane mud cake. 
Table 1 - Plant height as affected by PK (phosphate and potassium) fertilization, at different times (days after plantation) of growth, mixed with OM - Organic Matter (earthworm compost) applied in different rates with and without sugarcane filter mud cake (SFMC).

\begin{tabular}{|c|c|c|c|c|c|}
\hline \multirow{2}{*}{$\begin{array}{l}\text { Growth time (days) } \\
\text { Fertilization }\end{array}$} & 100 & 150 & 200 & 250 & 300 \\
\hline & \multicolumn{5}{|c|}{ Plant height } \\
\hline & & & $\mathrm{cm}$ per plant & & \\
\hline \multicolumn{6}{|l|}{ SFMC (40 t ha-1) } \\
\hline PK Fertilizer ${ }_{1} 80+$ OM 5 & $29.3 \mathrm{a}$ & $61.4 \mathrm{ab}$ & $94.0 \mathrm{~b}$ & $134.5 \mathrm{ab}$ & $188.0 \mathrm{ab}$ \\
\hline PK Fertilizer ${ }_{2} 160+$ OM 10 & $34.6 \mathrm{a}$ & $62.3 \mathrm{ab}$ & $103.5 \mathrm{a}$ & $143.0 \mathrm{a}$ & $185.0 \mathrm{ab}$ \\
\hline PK Fertilizer $_{3} 240+$ OM 15 & $30.1 \mathrm{a}$ & $63.4 \mathrm{ab}$ & $102.5 \mathrm{a}$ & $142.5 \mathrm{a}$ & $191.7 \mathrm{a}$ \\
\hline PK Biofertilizer ${ }_{1} 80+$ OM 5 & 29.9 a & $61.8 \mathrm{ab}$ & $102.0 \mathrm{a}$ & $123.2 \mathrm{~b}$ & $177.5 b$ \\
\hline PK Biofertilizer ${ }_{2} 160+$ OM 10 & $27.6 \mathrm{a}$ & $68.1 \mathrm{a}$ & $99.0 \mathrm{ab}$ & $144.7 \mathrm{a}$ & $180.7 \mathrm{~b}$ \\
\hline PK Biofertilizer ${ }_{3} 240+$ OM 15 & $30.3 \mathrm{a}$ & $69.6 \mathrm{a}$ & $97.8 \mathrm{ab}$ & $138.7 \mathrm{ab}$ & $185.0 \mathrm{ab}$ \\
\hline Rocks $_{1} 160+$ OM 5 & $28.2 \mathrm{a}$ & $59.0 \mathrm{~b}$ & $89.0 \mathrm{~b}$ & $112.7 \mathrm{~b}$ & $173.0 \mathrm{~b}$ \\
\hline Rocks $_{2} 320+$ OM 10 & $29.0 \mathrm{a}$ & $60.6 \mathrm{~b}$ & $91.0 \mathrm{~b}$ & $112.5 b$ & $176.2 \mathrm{~b}$ \\
\hline Rocks $_{3} 480+$ OM 15 & $27.9 \mathrm{a}$ & $61.1 \mathrm{ab}$ & $92.5 b$ & $122.7 \mathrm{~b}$ & $172.0 \mathrm{bc}$ \\
\hline Control $\left(\mathrm{P}_{0} \mathrm{~K}_{0}\right)+\mathrm{OM} 15$ & $24.6 \mathrm{a}$ & $47.0 \mathrm{c}$ & $72.0 \mathrm{c}$ & $91.5 \mathrm{c}$ & $136.2 \mathrm{~d}$ \\
\hline \multicolumn{6}{|l|}{ Without SFMC } \\
\hline PK Fertilizer ${ }_{2} 160+$ OM 10 & $28.6 \mathrm{a}$ & $56.2 b$ & $89.0 \mathrm{~b}$ & $125.0 \mathrm{~b}$ & $187.0 \mathrm{ab}$ \\
\hline PK Biofertilizer ${ }_{2} 160+$ OM 10 & $26.9 \mathrm{a}$ & $60.4 a b$ & $92.1 \mathrm{~b}$ & $124.0 \mathrm{~b}$ & $179.5 b$ \\
\hline Rock $_{2} 320+$ OM 10 & $32.8 \mathrm{a}$ & $59.4 \mathrm{~b}$ & $94.0 \mathrm{~b}$ & $118.2 \mathrm{~b}$ & $160.5 c$ \\
\hline C.V. (\%) & 20.42 & 11.70 & 10.65 & 9.30 & 4.17 \\
\hline
\end{tabular}

RR (Recommended rate - IPA, 2008). PK Fertilizers and PK biofertilizers applied in rates (50, 100 and $150 \%$ Recommended rates - RR), equivalent to (kg ha-1): 1 $=80 ; 2=160$ and $3=240$. For Rocks $1=160 ; 2=320$ and $3=480$. C.V. (Coefficient of Variation). Data with the same letter are not significant as per Tukey's test $(p \leq 0.05)$.

Table 2 - Total sugarcane productivity- TSP $\left(\mathrm{tha}^{-1}\right)$ in two consecutive harvests as affected by PK fertilization treatments, with $\mathrm{OM}-$ Organic Matter (earthworm compost) with and without sugarcane filter mud cake (SFMC).

\begin{tabular}{|c|c|c|}
\hline \multirow[t]{2}{*}{ Fertilization treatments } & \multicolumn{2}{|c|}{$\begin{array}{l}\text { Total Sugarcane Productivity } \\
\text { (TSP }-\mathrm{tha}^{-1} \text { ) }\end{array}$} \\
\hline & First harvest & Second harvest \\
\hline SFMC (40 t ha $\left.{ }^{-1}\right)$ & \multicolumn{2}{|c|}{$\mathrm{t} \mathrm{ha}^{-1}$} \\
\hline PK Fertilizer ${ }_{1} 80+0 M 5$ & $70.5^{\mathrm{Ba}} \pm 1.21$ & $69.5^{\mathrm{Ca}} \pm 2.30$ \\
\hline PK Fertilizer $_{2} 160+$ OM 10 & $71.2^{\mathrm{Ba}} \pm 1.00$ & $73.2^{\mathrm{Ba}} \pm 0.85$ \\
\hline PK Fertilizer ${ }_{3} 240+$ OM 15 & $78.7^{\mathrm{Ba}} \pm 1.98$ & $80.2^{\mathrm{Ba}} \pm 1.33$ \\
\hline PK Biofertilizer ${ }_{1} 80+$ OM 5 & $65.7^{\mathrm{Bb}} \pm 2.57$ & $75.8^{\mathrm{Ba}} \pm 3.30$ \\
\hline PK Biofertilizer $_{2} 160+$ OM 10 & $72.2^{\mathrm{Bb}} \pm 2.32$ & $80.8^{\mathrm{Ba}} \pm 0.77$ \\
\hline PK Biofertilizer ${ }_{3} 240+$ OM 15 & $89.7^{\mathrm{Ab}} \pm 2.76$ & $94.2^{\mathrm{Aa}} \pm 2.80$ \\
\hline Rocks $\mathrm{PK}_{1} 160+\mathrm{OM} 5$ & $50.0^{\mathrm{Ca}} \pm 2.86$ & $50.9^{\mathrm{Da}} \pm 2.76$ \\
\hline Rocks $\mathrm{PK}_{2} 320+\mathrm{OM} 10$ & $62.0^{\mathrm{Ca}} \pm 1.61$ & $61.8^{\mathrm{ca}} \pm 1.00$ \\
\hline Rocks $\mathrm{PK}_{3} 480+\mathrm{OM} 15$ & $62.0^{\mathrm{Ca}} \pm 1.21$ & $64.5^{\mathrm{Ca}} \pm 1.23$ \\
\hline Control $\left(\mathrm{P}_{0}^{3} \mathrm{~K}_{0}\right)+\mathrm{OM} 15$ & $43.5^{\mathrm{Ea}} \pm 2.57$ & $41.5^{\mathrm{Ea}} \pm 2.80$ \\
\hline \multicolumn{3}{|l|}{ Without SFMC } \\
\hline PK Fertilizer $_{2} 160$ OM 10 & $56.2^{\mathrm{Da}} \pm 2.86$ & $56.6^{\mathrm{Da}} \pm 2.82$ \\
\hline PK Biofertilizer $_{2} 160+$ OM 10 & $65.5^{\mathrm{Ca}} \pm 2.81$ & $65.9^{\mathrm{ca}} \pm 2.56$ \\
\hline Rock $\mathrm{PK}_{2} 320+\mathrm{OM} 10$ & $50.5^{\mathrm{Da}} \pm 1.98$ & $49.2^{\mathrm{Ea}} \pm 1.98$ \\
\hline
\end{tabular}

Data with the same letter are not significantly different (capital letters comparing the fertilization treatments and low letters compare the two crop harvest) as per Tukey's test $(p \leq 0.05)$.

The effects of the fertilization treatments on the industrial characteristics of the sugarcane crops are shown in Table 3 . The application of organic biofertilizer exhibited no significant difference $(p>0.05)$ with regard to purity and fiber characteristics when compared with other fertilization treatments. In general, the PK rock biofertilizer exhibited better plant parameters, probably due to the effects of nutrient availability in the soil. The biofertilizer and the mineral soluble fertilizer applied at the highest dosage rate exhibited the best results when compared with other fertilization treatments. Stamford et al., (2008) reported significant effects of PK rock biofertilizers inoculated with Acidithiobacillus on some characteristics of sugarcane and observed the best effectiveness when compared with mineral NPK fertilizer.

The data regarding total soluble solids (Brix) and apparent sucrose (Pol) for the different fertilization treatments are also shown in Table 3 . The best Brix and Pol sucrose values were produced by the treatment with PK rock biofertilizer, which agrees with Santos et al., (2010), who also found greater Brix and Pol values when sugarcane was fertilized with mud cake. The Brix results demonstrate the advantage of applying biofertilizer at 100 and $150 \%$ of the RDR, especially at the higher dosage rate. The Pol values were greater when the PK rock biofertilizer was applied at a dosage rate of $150 \%$ and mixed with sugarcane mud cake. In summary, the Brix and Pol analyses revealed the effectiveness of the PK rock biofertilizer mixed with sugarcane mud cake, which promoted a good nutritional response in the sugarcane crop.

The total Pol per hectare (TPH) and total sugar (TS) reflected the effects of the fertilization treatments; the effects were considerable for the PK rock biofertilizer and the mineral soluble application compared with other treatments, especially when applied at the higher dosage rates. These results agree with Santos et al., (2010). 
The effects of the fertilization treatments on several soil attributes during the two consecutive harvests are shown in Table 4. A low soil $\mathrm{pH}$ may influence the development of plants, which was observed by Stamford et al., (2006), who used P rock biofertilizers and sulfur inoculated with Acidithiobacillus bacteria. However, in the present study, the effects of low $\mathrm{pH}$ on sugarcane were not observed because the rock biofertilizer was mixed with OM (earthworm compost), which has a naturally neutral $\mathrm{pH}$. The biofertilizer treatment with sugarcane mud cake had no effect on the soil $\mathrm{pH}$ in our experiment. Several studies have reported the effects of
PK rock biofertilizers on soil $\mathrm{pH}$, especially when applied in high doses. These effects are due to the sulfuric acid produced by the oxidative bacteria Acidithiobacillus and because the biofertilizer has a low $\mathrm{pH}$ (approximately 3.0-3.5). However, our PK rock biofertilizer was mixed with sugarcane mud cake in a proportion of OM: $\mathrm{BP}+\mathrm{BK}$, equivalent to 3.0:0.5+0.5, and the $\mathrm{OM}$ (earthworm compost) had a $\mathrm{pH}$ of approximately 7.9 , which neutralized the PK rock fertilizer acidity. Stamford et al., $(2006,2007)$ described the effects of a mixed biofertilizer on soil $\mathrm{pH}$ reduction when applied in higher doses.

Table 3 - Quality of sugarcane juice and total sugar production of the first harvest as affected by PK fertilization treatments, with OM (earthworm compost) at three dosage rates with and without sugarcane filter mud cake (SFMC).

\begin{tabular}{|c|c|c|c|c|c|}
\hline \multirow{2}{*}{ Treatments } & \multicolumn{5}{|c|}{ Quality of Juice and total sugar production } \\
\hline & Brix $^{1}$ & Purity & Fiber & $\mathrm{TPH}^{1}$ & $\mathrm{TS}^{1}$ \\
\hline SFMC (40 t ha-1) & - & $-\%-$ & - & Pol t ha-1 & $\mathrm{tha}^{-1}$ \\
\hline PK Fertilizer $180+$ OM 5 & $13.09 \mathrm{a}$ & $89 a$ & $14.5 \mathrm{a}$ & $9.1 b$ & 135.6 a \\
\hline PKFertilizer $_{2} 160+$ OM 10 & $13.74 \mathrm{a}$ & $89 a$ & $14.0 \mathrm{a}$ & $11.2 \mathrm{a}$ & $138.3 a$ \\
\hline PKFertilizer $_{3} 240+$ OM 15 & 13.67 a & $85 a$ & $14.1 \mathrm{a}$ & $11.1 \mathrm{a}$ & $138.9 a$ \\
\hline PKBiofertilizer $_{1} 80+$ OM 5 & $13.25 \mathrm{a}$ & $84 a$ & $14.1 \mathrm{a}$ & $9.8 a b$ & $134.8 a$ \\
\hline PKBiofertilizer $_{2} 160+$ OM 10 & $13.71 \mathrm{a}$ & $84 a$ & $14.4 \mathrm{a}$ & $11.9 \mathrm{a}$ & $144.0 \mathrm{a}$ \\
\hline PKBiofertilizer $240+$ OM 15 & $13.75 \mathrm{a}$ & $85 a$ & $14.6 \mathrm{a}$ & $11.4 \mathrm{~b}$ & $139.5 a$ \\
\hline Rock PK $160+$ OM 5 & $12.15 b$ & $85 a$ & $14.0 \mathrm{a}$ & $7.9 \mathrm{c}$ & $123.7 b$ \\
\hline Rock PK $320+$ OM 10 & $12.66 \mathrm{~b}$ & $83 a$ & $14.6 \mathrm{a}$ & $7.8 \mathrm{c}$ & $128.0 \mathrm{~b}$ \\
\hline Rock PK ${ }^{2} 480+$ OM 15 & $12.74 \mathrm{~b}$ & $86 a$ & $14.7 \mathrm{a}$ & 7.9 & $129.8 b$ \\
\hline $\begin{array}{l}\text { Control }\left(\mathrm{P}_{0} \mathrm{~K}_{0}\right)+\mathrm{OM} 15 \\
\text { Without SFMC }\end{array}$ & $10.03 d$ & $86 a$ & $14.8 \mathrm{a}$ & $5.6 d$ & $109.9 c$ \\
\hline PKFertilizer $_{2} 160+$ OM 10 & $10.94 \mathrm{c}$ & $82 \mathrm{a}$ & $14.5 \mathrm{a}$ & $7.7 c$ & $121.0 \mathrm{~b}$ \\
\hline PKBiofertilizer $_{2} 160+$ OM 10 & $10.92 \mathrm{c}$ & $84 a$ & $14.2 \mathrm{a}$ & $6.0 \mathrm{~d}$ & $120.7 b$ \\
\hline PKRocks, 320 + OM 10 & $10.75 \mathrm{c}$ & $85 a$ & $14.9 \mathrm{a}$ & $6.0 \mathrm{~d}$ & $120.4 \mathrm{~b}$ \\
\hline
\end{tabular}

'Data with the same letter are not significantly different as per Tukey's test $(p \leq 0.05)$; TPH $=$ Total Pol per hectare; TS = Total Sugar.

Table 4 - Soil attributes ( $\mathrm{pH}$, available $\mathrm{P}$ and $\mathrm{K}$ ) as affected by different PK fertilization treatments on sugarcane crops (first and second harvest), with and without sugarcane filter mud cake (SFMC).

\begin{tabular}{|c|c|c|c|c|c|c|}
\hline \multirow{2}{*}{ Treatments* } & $\mathrm{pH}$ & $\mathrm{P}\left(\mathrm{mg} \mathrm{dm}^{-3}\right)$ & $\mathrm{K}\left(\mathrm{cmol}_{\mathrm{c}} \mathrm{dm}^{-3}\right)$ & $\mathrm{pH}$ & $P\left(\mathrm{mg} \mathrm{dm}^{-3}\right)$ & $\mathrm{K}\left(\mathrm{cmol}_{\mathrm{c}} \mathrm{dm}^{-3}\right)$ \\
\hline & \multicolumn{3}{|c|}{ First harvest } & \multicolumn{3}{|c|}{ Second harvest } \\
\hline \multicolumn{7}{|l|}{ SFMC (40 t ha-1) } \\
\hline PK Fertilizer ${ }_{1} 80+0 \mathrm{OM} 5$ & 5.60 & $17 \mathrm{bB}$ & $0.76 \mathrm{cB}$ & 5.60 & $35 \mathrm{cA}$ & $2.8 \mathrm{aA}$ \\
\hline PK Fertilizer ${ }_{2} 160+$ OM 10 & 5.61 & $24 \mathrm{aB}$ & $1.28 \mathrm{aB}$ & 5.77 & $36 \mathrm{cA}$ & $2.8 \mathrm{aA}$ \\
\hline PK Fertilizer ${ }_{3} 240+$ OM 15 & 5.62 & $23 \mathrm{aB}$ & $1.38 \mathrm{aB}$ & 5.62 & $72 \mathrm{abA}$ & $2.8 \mathrm{aA}$ \\
\hline PK Biofertilizer ${ }_{1} 80+$ OM 5 & 5.81 & $18 \mathrm{bB}$ & $0.74 \mathrm{cB}$ & 5.72 & $39 \mathrm{cA}$ & $2.8 \mathrm{aA}$ \\
\hline PK Biofertilizer ${ }_{2} 160+$ OM 10 & 5.45 & $24 \mathrm{aB}$ & $1.22 \mathrm{aB}$ & 5.70 & $68 \mathrm{bA}$ & $2.9 \mathrm{aA}$ \\
\hline PKBiofertilizer $_{3} 240+$ OM 15 & 5.41 & $27 \mathrm{aB}$ & $1.37 \mathrm{aB}$ & 5.27 & $95 \mathrm{aA}$ & $2.8 \mathrm{aA}$ \\
\hline PK Rock $_{1} 160$ + OM 5 & 5.98 & $17 \mathrm{bA}$ & $1.09 \mathrm{bA}$ & 5.75 & $30 \mathrm{cA}$ & $0.7 \mathrm{cB}$ \\
\hline PK Rock $320+$ OM 10 & 5.87 & $20 \mathrm{bA}$ & $1.17 \mathrm{abA}$ & 5.72 & $35 \mathrm{cA}$ & $0.8 \mathrm{cB}$ \\
\hline PK Rock $_{3}^{2} 480+$ OM 15 & 5.88 & $20 \mathrm{bB}$ & $1.23 \mathrm{abA}$ & 5.78 & $37 \mathrm{cA}$ & $0.8 \mathrm{cB}$ \\
\hline Control $\mathrm{P}_{0}^{3} \mathrm{~K}_{0}+\mathrm{OM} 15$ & 5.52 & $14 \mathrm{bA}$ & $0.90 \mathrm{bA}$ & 5.60 & $12 \mathrm{dA}$ & $0.8 \mathrm{cA}$ \\
\hline \multicolumn{7}{|l|}{ Without SFMC } \\
\hline PK Fertilizer ${ }_{2} 160+$ OM 10 & 5.76 & $20 \mathrm{bB}$ & $1.24 \mathrm{abB}$ & 5.87 & $35 \mathrm{cA}$ & $1.8 \mathrm{bA}$ \\
\hline PK Biofertilizer ${ }_{2} 160$ + OM 10 & 5.87 & $21 \mathrm{bB}$ & $0.92 \mathrm{bB}$ & 5.85 & $72 \mathrm{abA}$ & $1.9 \mathrm{bA}$ \\
\hline PK Rock $2320+$ OM 10 & 5.75 & $16 \mathrm{bB}$ & $0.94 \mathrm{abA}$ & 5.47 & $72 \mathrm{abA}$ & $0.9 \mathrm{cA}$ \\
\hline
\end{tabular}

${ }^{*}$ Data with the same letter are not significantly different (small letters comparing the fertilization treatments and capital letters compare the crop harvest) as per Tukey's test $(p \leq 0.05)$. 
In relation to available $\mathrm{P}$ and $\mathrm{K}$, a significant effect was identified when we applied the PK biofertilizer and mineral soluble fertilizer (Table 4). It is important to describe the residual effect of these PK sources, especially the biofertilizer mixed with sugarcane mud cake, which exhibited higher amounts of available $\mathrm{P}$ and $\mathrm{K}$ in the two consecutive crop harvests. The PK biofertilizer had the best available $\mathrm{P}$ and $\mathrm{K}$ levels in the soil, and the biofertilizer and soluble fertilizer without OM (earthworm compost) had superior residual effects compared with the PK rock treatment, and these results agree with Berger et al., (2013). The application of $\mathrm{P}$ and $\mathrm{K}$ biofertilizers in tableland soils (Stamford et al., 2006) increased the sugarcane stalk yield and affected several soil chemical attributes, especially when applied at the recommended dosage rates.

\section{Conclusions}

The PK rock biofertilizer influenced plant parameters and technical characteristics of the sugarcane harvests studied. The PK rock biofertilizer and earthworm compost promoted the best results. We conclude that biofertilizers produced from PK rocks with the addition of sulfur from Acidithiobacillus and earthworm compost may be a viable alternative to soluble fertilizers for sugarcane grown in soils with low available $\mathrm{P}$ and $\mathrm{K}$.

\section{Acknowledgements}

Thanks to the Brazilian National Council for Scientific and Technological Development (CNPq), the Coordination for the Improvement of Higher Level Personnel (CAPES), and the Foundation for Science and Technology of the State of Pernambuco (FACEPE) for the financial support and scholarships. We are also grateful to the Santa Teresa Sugarcane Industry for the conducting of the experiment and the technical analyses made in the Industry laboratory and to the Biotech Environmental Company for organic matter acquisition.

\section{References}

Berger, L.R.R.; Berger, L.R.; Stamford, N.P.; Santos, C.E.R.S.; Freitas, A.D.S.; Franco, L.O.; Stamford, T.C.M. 2013. Plant and soil characteristics affected by biofertilizers from rocks and organic matter inoculated with diazotrophic bacteria and fungi that produce chitosan. Journal of Soil Science and Plant Nutrition 13: 592-603.

Dario, F.R.; De Vincenzo, M.C.V.; Cardelli, R.; Miklos, A.A.D.; Levi-Minzi, R.; Kaemmerer, M. 2003. Application of compost elaborated with sugarcane (Saccharum officinarum L.) crop residues. Fresenius Environmental Bulletin 12: 1379-1383.

Elsayed, M.T.; Babiker, M.H.; Abdelmalik, M.E.; Mukhtar, O.N.; Montange, D. 2008. Impact of filter mud application on the germination of sugarcane and small seeded plants and on soil and sugarcane nitrogen contents. Bioresource Technology 99: 181-186.
El-Tarabily, K.A.; Soaud, A.A.; Saleh, M.E.; Matsumoto, S. 2006. Isolation and characterization of sulfur bacteria, including strains of Rhizobium from calcareous soils and their effects on nutrient uptake and growth of maize. Australian Journal of Agricultural Research 57: 101-111.

Empresa Brasileira de Pesquisa Agropecuária [Embrapa]. 2009. Mannual for Chemical Analyzes in Soils, Plants and Fertilizers = Manual de Análises Químicas De Solos, Plantas e Fertilizantes. Embrapa-CNPS, Rio de Janeiro, RJ, Brazil (in Portuguese).

Instituto Agronômico de Pernambuco [IPA]. 2008. Fertilization Recommended for Pernambuco State $=$ Recomendações de Adubação para o Estado de Pernambuco. IPA, Recife, PE, Brazil (in Portuguese).

Kaur, K.; Kapoor, K.K.; Gupta, A.P. 2005. Impact of organic manures with and without mineral fertilizers on soil chemical and biological properties under tropical conditions. Journal of Plant Nutrition and Soil Science 168: 117-122.

Lima, F.S.; Stamford, N.P.; Sousa, C.S.; Lira Junior, M.A.; Malheiros, S.M.M.; Straaten, P. van. 2010. Earthworm compound and rock biofertilizer enriched in nitrogen by inoculation with free living diazotrophic bacteria. World Journal of Microbiology and Biotechnology 27: 1769-1777.

Oliveira, W.S.; Stamford, N.P.; Silva, E.V.N.; Santos, C.E.R.S.; Freitas, A.D.S.; Arnaud, T.M.S.; Sarmento, B.F. 2014. Biofertilizer produced by interactive microbial processes affects melon yield and nutrients availability in a Brazilian semiarid soil. Australian Journal of Crop Science 8: 1124-1131.

Santos, D.H.; Tiritan, C.S.; Foloni, J.S.S.; Fabris, L.B. 2010. Sugarcane yield under mud cake addition enriched with soluble phosphate. Tropical Agricultural Research 40: 454-461.

Stamford, N.P.; Andrade, I.P.; Silva Junior, S.; Santos, C.E.R.S.; Lira Junior, M.A.; Freitas, A.D.S.; Straaten, V.P. 2011. Nutrient uptake by grape in a Brazilian soil affected by rock biofertilizer. Journal of Soil Science and Plant Nutrition 11: 79-88.

Stamford, N.P.; Lima, R.A.; Santos, C.E.R.S. 2008. Effectiveness of phosphate and potash rocks with Acidithiobacillus on sugarcane yield and their effects in soil chemical attributes. World Journal of Microbiology and Biotechnology 24: 2061-2066.

Stamford, N.P.; Santos, P.R.; Santos, C.E.R.S.; Freitas, A.D.S.; Dias, S.H.L.; Lira Junior, M.A. 2007. Agronomic effectiveness of biofertilizers with phosphate rock, sulphur and Acidithiobacillus in a Brazilian tableland acidic soil grown with yam bean. Bioresource Technology 98: 1311-1318.

Stamford, N.P.; Lima, R.A.; Santos, C.E.R.S.; Dias, S.H.L. 2006. Rock biofertilizers with Acidithiobacillus on sugarcane yield and nutrient uptake in a Brazilian soil. Geomicrobiology Journal 23: 261-265.

Straaten, P. van. 2007. Agrogeology: the use of rocks for crops. Enviroquest, Cambridge, UK. 